\title{
PENDIDIKAN ISLAM UNTUK ANAK BERKEBUTUHAN KHUSUS (Kajian tentang Konsep, Tanggung Jawab dan Strategi Implementasinya)
}

\author{
Pristian Hadi Putra, Indah Herningrum, Muhammad Alfian \\ Institut Agama Islam Negeri Kerinci \\ E-mail: fristianhp87@gmail.com, indah.hotmail@gmail.com, fiyan.uin1@gmail.com
}

\begin{abstract}
How to Cite:
Putra.P.H., Herningrum.I., Alfian.M., Hanum. L. (2021). Tanggung Jawab Pendidikan Islam Terhadap Anak Berkebutuhan Khusus dan Strategi Implementasinya. Fitrah: Journal of Islamic Education, 2(1), 80-95.
\end{abstract}

ARTICLE HISTORY
$\begin{array}{lll}\text { Received }: 31 & \text { May } & 2021 \\ \text { Revised }: 13 & \text { July } & 2021 \\ \text { Accepted }: 13 & \text { July } & 2021 \\ \text { Published : } 19 & \text { September } 2021\end{array}$

\section{KEYWORDS:}

Disability, Disabled, Islamic Education, Educational Responsibilities

\section{ABSTRACT}

This study aims to analyze concept, the responsibility of Islamic education to children with special needs and its implementation strategy. This research uses library research method. Data analysis was carried out using content analysis, where each finding from the literature search was analyzed in depth to obtain uniqueness. The results of this study indicate that children with special needs should receive special attention so that they can be equal and do not feel different from other normal children. The responsibilities of Islamic education for children with special needs, namely; 1) active role of government. the government has provided, 2) strengthening the mental condition of parents, 3) adequate social support. Regarding the implementation of responsibilities, it is carried out by implementing learning strategies so that they can be optimized by making modifications (content, process, evaluation), functional, task analysis, individual learning, peer learning. In addition, inclusive education can also be carried out which provides opportunities for all students who have disabilities and have the potential for intelligence to participate in education in an educational environment together.

\section{RIWAYAT ARTIKEL \\ Diterima :31 Mei 2021 \\ Direvisi :13 Juli 2021 \\ Disetujui :13 Juli 2021 \\ Diterbitkan :19 September 2021}

\section{KATA KUNCI:}

Disabilitas, Difabel, Pendidikan Islam, Tanggung Jawab Pendidikan

\section{ABSTRAK}

Penelitian ini bertujuan untuk menganalisis konsep, tanggung jawab pendidikan Islam terhadap anak berkebutuhan khusus serta strategi implementasinya. Penelitian ini menggunakana metode penelitian pustaka. Analisis data dilakukan menggunakan analisis konten, dimana setiap temuan dari penelurusan pustaka dianalisis secara mendalam untuk mendapatkan kekhasan. Hasil penelitian ini menunjukkan bahwa anak yang berkebutuhan khusus harus mendapatkan perhatian khusus agar mereka bisa setara dan tidak merasa berbeda dari anak normal lainnya. Adapun tanggung jawab Pendidikan Islam terhadap anak berkebutuhan khusus, yaitua; 1) peran aktif pemerintah. pemerintah telah memberikan, 2) penguatan kondisi mental orang tua, 3) dukungan sosial yang memadai. Berkaitan dengan implemetasi tanggung jawab dilaksanakan dengan melakukan strategi pembelajaran agar dapat optimal dengan melakukan modifikasi (isi, proses, evaluasi), fungsional, analisis tugas, pembelajaran individu, pembelajaran teman sebaya. Selain itu dapat juga dilakukan pendidikan inklusi yang memberikan kesempatan kepada semua peserta didik yang memiliki kelainan dan memiliki potensi kecerdasan untuk mengikuti pendidikan dalam lingkungan pendidikan secara bersama-sama. 


\section{Fitrah: Journal of Islamic Education}

\section{PENDAHULUAN}

Pendidikan merupakan hal yang penting bagi seluruh anak karena dengan pendidikan martabat seorang anak akan diakui di masyarakat. Akan tetapi tidak setiap anak yang dilahirkan di dunia ini selalu mengalami perkembangan normal. Banyak di antara mereka yang dalam perkembangannya mengalami hambatan, gangguan, kelambatan, atau memiliki faktor-faktor resiko sehingga untuk mencapai perkembangan optimal diperlukan penanganan atau intervensi khusus. Kelompok inilah yang kemudian dikenal sebagai anak berkebutuhan khusus atau anak luar biasa. Anak disabilitas selalu dipandang sebelah mata oleh masyarakat karena terlahir dengan sebuah kekurangan. Masyarakat juga menilai anak difabel tidak perlu mendapatkan pendidikan. Menurut mereka, sia-sia saja anak difabel belajar di sekolah. (Perdana \& Dewi, 2015). Namun, hal ini tidak menurunkan semangat anak difabel untuk sekolah dengan didirikannya sekolah luar biasa (SLB) oleh pemerintah. Pada kenyataannya, banyak prestasi-prestasi yang diukir dari anak difabel di kancah nasional maupun internasional. (Pratiwi, 2016).

Kecacatan bagi sebagian orang merupakan suatu masalah yang berat serta dapat menghambat cita-cita dan aktivitas. Permasalahan yang dihadapi penyandang cacat bukan hanya masalah psikologis seperti rendah diri, merasa tidak mampu dan tidak berdaya, menutup diri dan tidak percaya diri untuk bergaul di tengah kehidupan masyarakat bahkan sebagian dari mereka ingin mengakhiri hidup mereka saja, karena seringkali mereka mendapat perlakuan yang berbeda ketika ia di tengah masyarakat yang membuat mereka sangat menderita menjalani hidup dengan keadaannya, mereka bahkan di hina dan diragukan apapun yang mereka lakukan. (Udhiyanasari, 2019). Hal tersebut tentu merupakan sikap yang salah yang ditunjukkan oleh penderita disabilitas, hal tersebut terjadi karena kurangnya pemahaman bagi penderita disabilitas tentang dirinya dan lingkungannya, karena sesungguhnya mereka memiliki hak yang sama dengan masyarakat normal pada umumnya. Bukan hanya memiliki hak yang sama, kesempatan apapun di dunia ini juga berlaku untuk penderita disabilitas, sering kali penderita disabilitas dapat lebih berprestasi dengan kemampuan mereka yang mungkin selama ini terpendam, maka dari itu diperlukan penyikapan yang baik dan benar agar penderita disabilitas tidak merasa ditindas maupun rendah diri di tengah masyarakat. (Amin, 2017).

Oleh karena masalah yang disebutkan di atas, dianggaop penting untuk dilakukan penelitian mengenai cara yang baik dalam menyikapi penderita disabilitas. Penelitian ini akan memberikan wawasan seputar disabilitas dan cara menyikapinya sesuai dengan khazanah pendidikan Islam, serta strategi mengimplementasikannya dalam praktik pendidikan formal maupun nonformal. 
Terdapat beberapa penelitian yang relevan dengan penelitian ini, seperti perencanaan pembelajaran untuk anak berkebutuhan khusus (Anwar \& Zaenullah, 2020), pembelajaran pendidikan agama Islam bagi anak berkebutuhan khusus (Maftuhin \& Fuad, 2018), strategi pembelajaran pendidikan agama Islam untuk anak berkebutuhan khusus tipe tunarungu (Zein, 2018), kebijakan pendidikan untuk anak berkebutuhan khusus di kota Surabaya (Rachman, 2020), analisis pembelajaran anak berkebutuhan khusus pada kurikulum 2013 (Zulaikhah et al., 2021), pembelajaran pendidikan agama Islam bagi anak berkebutuhan khusus (Hanum, 2014), implementasi pendidikan inklusi untuk anak berkebutuhan khusus (Wathoni, 2013). Berdasarkan ragam penelitian relevan tersebut terdapat perbedaan antara penelitian lalu dengan penelitian ini, novelty-nya penelitian tidak hanya mengkhususkan bagaimana pandangan Islam terkait dengan pendidikan tersebut akan tetapi juga membahas tentang strategi implementasi konsep tersebut.

Secara khusus penelitian ini bertujuan pada dua hal yakni: (1) tanggung jawab pendidikan Islam terhadap anak berkebutuhan khusus, (2) strategi implementasi konsep pendidikan Islam untuk anak berkebutuhan khusus. Penelitian ini tentunya berkontribusi untuk guru, lembaga pendidikan, dan juga orang tua terutama untuk memperlakukan anak disabilitas memenuhi hak pendidikannya.

\section{KAJIAN TEORI}

Anak berkebutuhan khusus di definisikan sebagai anak yang memerlukan pendidikan dan layanan khusus untuk mengembangkan potensi kemanusiaan mereka secara sempurna. Penyebutan sebagai anak berkebutuhan khusus, dikarenakan dalam memenuhi kebutuhan hidupnya, anak ini membutuhkan bantuan layanan pendidikan, layanan sosial, layanan bimbingan dan konseling, dan berbagai jenis layanan lainnya yang bersifat khusus. Dalam percakapan sehari hari, anak berkebutuhan khusus dijuluki sebagai "orang luar biasa", dikarenakan mereka memiliki kelebihan yang luar biasa, misalnya orang yang terkenal memiliki kemampuan intelektual yang luar biasa, memiliki kreatifitas yang tinggi dalam melahirkan suatu temuan-temuan yang luar biasa dibidang iptek, religius, dan di bidangbidang kehidupan lainnya. Dalam dunia pendidikan, kata luar biasa juga merupakan julukan atau sebutan bagi mereka yang memiliki kekurangan atau mengalami berbagai kelainan dan penyimpangan yang tidak di alami oleh orang normal pada umumnya. Kelainan atau kekurangan itu dapat berupa kelainan dalam segi fisik, psikis, sosisal, dan moral. (Dermawan, 2013).

Disabilitas atau difabel adalah penyandang cacat. Sedangkan, menurut Penguin Dictionary of Psychologydisabilityis "Generally, any lack of ability to perform some fuction more specifically, a cogenital impairment or loss of 
fuction through trauma, disaese, etc' Orang-orang berkebutuhan khusus disebut juga dengan istilah "difabel". Kata difabel berasal dari kata different ability atau orang-orang berkemampuan berbeda. Istilah ini diciptakan untuk mengganti label disable atau disability, yang berarti penyandang cacat. (Sheehy et al., 2016). Kedua kata tersebut jika mengikuti pendefinisian the Sosial Work Dictionary adalah reduksi fungsi secara permanen atau temporer serta ketidakmampuan seseorang untuk melakukan sesuatu yang mampu dilakukan orang lain sebagai akibat dari kecacatan fisik maupun mental. Difabel atau disabilitas adalah istilah yang meliputi gangguan, keterbatasan aktivitas, dan pembatasan partisipasi. Gangguan adalah sebuah masalah pada fungsi tubuh atau strukturnya suatu pembatasankegiatan adalah kesulitan yang dihadapi oleh individu dalam melaksanakan tugas atau tindakan, sedangkan pembatasan partisipasi merupakan masalah yang dialami oleh individu dalam keterlibatan dalam situasi kehidupan. Jadi disabilitas adalah sebuah fenomena kompleks, yang mencerminkan interaksi antara ciri dari tubuh seseorang dan ciri dari masyarakat tempat dia tinggal. (Sahara et al., 2020).

Sekarang ini para penyandang difabel masih sering kali dipandang sebelah mata bagi masyarakat luas, hal ini dikarenakan oleh beberapa faktor beberapa diantaranya disebabkan oleh keterbatasan mereka untuk melakukan suatu aktivitas dan keterbatasan mereka terhadap kemampuan fisik mereka.
Pandangan masyarakat yang negatif terhadap kelompok difabel juga menyebabkan kelompok tersebut sulit untuk mendapatkan kedudukan, hak, kewajiban dan peran yang sama dengan masyarakat lainnya di segala aspek kehidupan dan penghidupan.

Dalam dunia pendidikan, anak berkebutuhan khusus di klasifikasikan atas beberapa kelompok sesuai dengan jenis kelainan anak. Berikut ini akan dijelaskan beberapa jenis-jenis anak berkebutuhan khusus, sebagai berikut: (1). Anak Tuna Netra. Mengenai istilah tunanetra itu sendiri, banyak versi yang menyebutkan arti dari istilah tersebut. Menurut Kamus Besar Bahasa Indonesia pengertian tunanetra ialah tidak dapat melihat, atau anak yang mempunyai kekurangan secara indrawi, yakni indra penglihatan. Meskipun indra penglihatannya bermasalah, intelegensi yang mereka miliki masih dalam taraf normal. Hal-hal yang berhubungan dengan mata diganti dengan indra lain sebagai kompensasinya, (2). Anak Tuna Rungu. Menurut Kamus Besar Bahasa Indonesia, tunarungu adalah istilah lain dari tuli yaitu tidak dapat mendengar karena rusak pendengaran, secara etimologi, tunarungu berasal dari kata "tuna" dan "rungu". Tuna artinya kurang dan rungu artinya pendengaran. Jadi orang dikatakan tunarungu apabila ia tidak mampu mendengar atau kurang mampu mendengar suara. Pengertian tunarungu sendiri sangat beragam yang mengacu pada kondisi pendengaran anak tunarungu. 
Tunarungu juga merupakan suatu istilah umum yang menunjukkan kesulitan mendengar dari yang ringan sampai yang berat, digolongkan ke dalam tuli dan kurang dengar, (3). Anak Tuna Daksa. Tunadaksa merupakan sebutan halus bagi orang-orang yang memiliki kelainan fisik, khususnya anggota badan, seperti kaki, tangan, atau bentuk tubuh. Antara anak normal dan tunadaksa, memiliki peluang yang sama untuk melakukan aktualisasi diri. Hanya saja, banyak orang yang meragukan kemampuan dari anak tunadaksa. Perasaan iba yang berlebihan selalu membuat seseorang tidak mengizinkan anak tunadaksa untuk melakukan kegiatan fisik. Dengan adanya ketunaan pada mereka, eksistensinya sering terganggu, (4). Anak Tuna Wicara. Adalah anak yang mengalami kelainan pada proses berbicara atau berbahasa. Anak yang seperti ini mengalami kesulitan dalam berbahasa atau berbicara sehingga tidak dapat dimengerti oleh orang lain, (5). Tuna Grahita. Tunagrahita merupakan istilah yang digunakan untuk menyebut anak atau orang yang memiliki kemampuan intelektual di bawah rata-rata atau bisa juga disebut dengan redartasi mental. Tunagrahita ditandai dengan keterbatasan intelegensi dan ketidakcakapan dalam interaksi sosial. (6). Autis. Autisme adalah suatu kondisi mengenai seseorang yang didapatkannya sejak lahir atau masa balita, yang membuat dirinya tidak dapat berhubungan sosial atau komunikasi secara normal. Ditinjau dari bahasa, autis berasal dari bahasa Yunani yang "sendiri". Hal ini dilatarbelakangi karena anak autis pada umumnya hidup dengan dunianya sendiri. Menikmati kesendirian dan tak ada seorangpun yang mau mendekatinya selain orang tuanya. (Hasbi \& Restuningsih, 2018).

Selanjutnya, terdapat beberapa teori yang berkaitan dengan tanggung jawab Pendidikan Islam, di antaranya sebagaimana dikemukakan oleh Nashih Ulwan dalam kitabnya Tarbiyatul Aulad:

1. Tanggung Jawab Pendidikan Iman (Tauhid), Syeikh Ahmad Farid menguraikan bahwa pendidikan iman adalah upaya meningkatkan kualitas iman generasi muda islam dan memupuk pohon iman yang ada dalam hati mereka dengan cara memperdalam pengetahuan mereka tentang tauhid, merenungkan isi kandungan al-Quran dan mengenal sosok dan profil nabi Muhammad SAW (Farid: 2011).

2. Tanggung Jawab Pendidikan Ahlak, dalam Islam Pendidikan Ahlak biasa dipahami sebagai sebuah latihan Psikis dan fisik. Latihan ini dapat menciptakan seseorang yang memiliki kebiasaan untuk menjalankan perintah Allah dengan rasa tanggung jawab yang tinggi (Abdullah: 2007). Peran gurulah yang bisa membimbing dan mengarahkan siswa untuk memiliki ahlak yang baik dan tinggi.

3. Tanggung jawab pendidikan fisik, dalam hal tanggung jawab fisik ini, terdapat beberapa hal yang diajarkan dalam Islam 
untuk menjaga fisik agar tetap prima, diantaranya: memberi nafkah pada anak dengan hasil dari yang halal; memakan dan meminum makanan yang sehat serta tidur yang teratur; mengindari diri dari penyakit menular; menghindari sesuatu yang tidak bermanfaat; membiasakan anak untuk berolah raga; membiasakan anak untuk zuhud atau tidak hedon dan membiasakan anak untuk bekerja keras dan sungguhsungguh dalam melakukan sesuatu

4. Tanggung jawab pendidikan akal, ada beberapa hal yang bisa dilakukan guna merangsang berkembangnya intelektual anak diantaranya: menyiapkan kenyamanan belajar bagi anak, membiasakan anak untuk berpikir logis dalam menyelesaikan semua masalah, membiasakan anak berpikir sebab akibat dan membiasakan anak untuk berpikir objektif, dan bijaksana dalam mengambil sebuah keputusan

5. Tanggung jawab pendidikan sosial. Pendidikan sosial yang dimaksudkan adalah untuk membiasakan anak sedari kecil untuk melaksanakan adab sosial dengan baik yang didasarkan pada psikis yang baik dan bersumber pada ajaran islam agar tertanam rasa keimanan, sehingga nantinya dalam bermasyarakat nantinya dapat menampilkan perilaku dan ahlak yang baik, seimbang akan dan bijaksana dalam bertindak (Ulwan: 1993).

6. Tanggung jawab pendidikan seksual. Tanggung jawab pendidikan seksual adalah upaya untuk menanamkan dan memberikan pemahaman, pengajaran dan penyadaran kepada anak tentang masalah seksual, naluri dan perkawinan. Pendidikan seksual ini, bisa diberikan sesuai dengan perkembangan usia anak. (Ulwan, 2017).

\section{METODE PENELITIAN}

Jenis penelitian yang dipakai dalam penelitian ini adalah penelitian kepustakaan (Library research), dengan metodologi penelitian kualitatif. Melalui penelitian kulitatif diharapkan dapat memahami dan melihat fenomena yang terjadi dan dialami oleh subjek penelitian, baik yang berkenaan dengan proses, aktivitas, dan peristiwa atau mempelajari perilaku culture-sharing dari individu atau kelompok tertentu.

Dengan demikian penelitian yang dilakukan dalam penelitian ini untuk melihat fenomena dan mendeskripsikan tentang tanggung jawab pendidikan Islam terhadap anak berkebutuhan khusus (Difabel dan Disabilitas), Serta Strategi Dalam Implementasinya. Fokus kajian dalam penelitian ini adalah mengenai konklusi umum dari tanggung jawab pendidikan Islam terhadap keberadaan anak berkebutuhan khusus.

Karena berbentuk penelitian kepustakaan, sumber data yang digunakan adalah pemikiran cendekiawan muslim tentang pendidikan anak berkebutuhan khusus, seperti Abdullah Nashih Ulwan, Imam al-Ghazali, dan juga peraturan atau kebijakan pemerintah 
tentang penyelenggaran pendidikan, sumber data pustaka yang berupa buku, dokumen dan artikel ilmiah yang terkait dengan variabel penelitian yang diambil. Teknik pengumpulan data dilakukan dengan cara: pertama, melakukan pengumpulan sebanyak mungkin sumber pustaka yang mungkin terkait dengan variabel penelitian yang akan diteliti, kemudian dilakukan sortir terhadap sumber pustaka yang telah dikumpulkan. Sortir dalam hal ini menjadi penting, untuk mencari sumber pustaka yang dianggap memuat data yang bersifat primer, sekunder maupun tersier atau pelengkap saja. Hal terakhir dari pengumpulan data ini adalah penyajian data yang kemudian akan disusun menjadi sebuah karya ilmiah. Teknik analisis data yang dipakai adalah triangulasi sumber. Triangulasi digunakan agar data yang terkumpul bisa dianggap valid jika disandingkan dengan data lain yang serupa, dalam hal teks maupun konteksnya.

\section{HASIL DAN PEMBAHASAN PENELITIAN}

Tidak dapat dipungkiri, pengasuhan anak berkebutuhan khusus $(\mathrm{ABK})$ memerlukan tambahan energi, pemikiran, serta biaya yang lebih tinggi dibanding mengasuh anak-anak pada umumnya. berikut ini akan dijelaskan langkah-langkah dalam menangani anak berkebutuhan khusus di antaranya adalah sebagai berikut:

1. Penguatan kondisi mental orang tua

Strategi ini membutuhkan peranaktif orang tua dalam melakukan pengasuhan anak berkebutuhan khusus. Beberapa strategi yang dibutuhkan oleh orang tua anak berkebutuhan khusus diantaranya perlu menyediakan waktu untuk dirinya sendiri, bekerjasama dalam pengasuhan dengan pasangan, dan aktif dalam mencari informasi mengenai anak berkebutuhan khusus. Orangtua perlu menyediakan waktu untuk dirinya sendiri, sebagai bentuk apresiasi terhadap diri sendiri yang sudah menyediakan waktu ekstra dan tenaga sehari-hari untuk mengasuh anak berkebutuhan khusus. (Rani \& Jauhari, 2018).

2. Dukungan sosial yang memadai

Dukungan sosial memegang peranan luarbiasa bagi keberlangsungan pengasuhan anak berkebutuhan khusus. Dukungan sosial dapat berupa dorongan moral, yang menguatkan dari masyarakat sekitar maupun keluarga terdekat. Melalui dukungan sosial, diharapkan orang tua anak berkebutuhan khusus dapat berbagi pengalaman tentang pola asuh anak berkebutuhan khusus. Hal ini belum banyak terlihat di lingkungan masyarakat kita, mengingat masih kuatnya kepercayaan bahwa memiliki anak berkebutuhan khusus merupakan "karma" dari Tuhan. Sehingga, kecenderungan yang ada keluarga dengan anak berkebutuhan khusus cenderung "dikucilkan" masyarakat. Untuk menghapus kecenderungan ini, perlu peran pemerintah untuk memberikan edukasi kepada 
masyarakat umum tentang anak berkebutuhan khusus. Edukasi ini dapat disampaikan melalui jalur media atau pospos pelayanan masyarakat untuk menyentuh masyarakat di area pinggiran atau pedesaan. (Yulisetyaningrum et al., 2018).

3. Peran aktif pemerintah

Peran aktif pemerintah dalam menyediakan pelayanan kesehatan dan konsultasi yang dapatdijangkau masyarakat. Hal ini merupakan faktor yang sangat vital bagi masyarakat umum, terutama bagi mereka yang berada pada kelas sosial menengah kebawah. Tidak dapat dipungkiri, pelayanan konsultasi dan kesehatan masih merupakan sesuatuhal yang mahal.

Dengan menyediakan konsultasi anak berkebutuhan khusus yang mudah dijangkau masyarakat, diharapkan anak berkebutuhan khusus mendapat pelayanan konsultasi yang mudah dan murah. Pemerintahpun, harus menyediakan fasilitas penanganan anak berkebutuhan khusus secara terpadu. Saat ini, pemerintah sudah memberikan perhatian kepada anak berkebutuhan khusus melalui pembentukan Direktorat Pembinaan Sekolah Luar Biasa (PSLB) di bawah koordinasi Departemen Pendidikan dan Kebudayaan. (Darma \& Rusyidi, 2015).

Anak penyandang disabilitas sama seperti anak normal lainnya yang memiliki hak untuk diperlakukan secara adil dan derajat yang sama. Namun, masyarakat selalu menganggap anak difabel sebagai anak yang terlahir untuk meminta belas kasih dari orang lain dan beban bagi keluarganya. Dalam hal ini, Islam sudah memberi respon positif kepada anak penyandang disabilitas.
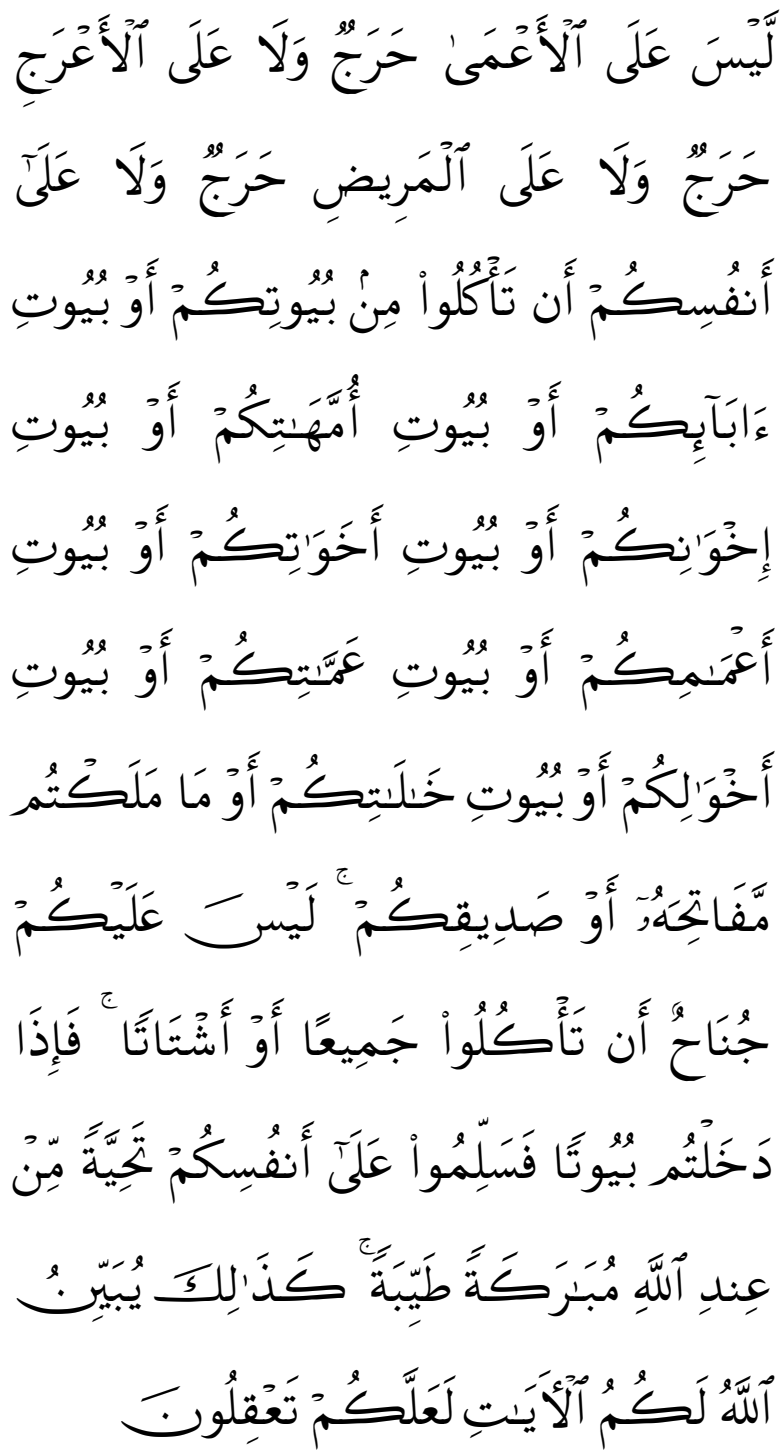

Artinya: tidak ada halangan bagi orang buta, tidak (pula) bagi orang pincang, tidak (pula) bagi orang sakit, dan tidak (pula) bagi dirimu sendiri, Makan (bersama-sama mereka) dirumah kamu sendiri atau dirumah bapak-bapakmu, dirumah ibu-ibumu, dirumah saudara- saudaramu yang laki-laki, di rumah saudaramu yang perempuan, dirumah saudara 
bapakmu yang laki-laki, dirumah saudara bapakmu yang perempuan, dirumah saudara ibumu yang lakilaki, dirumah saudara ibumu yang perempuan, dirumah yang kamu miliki kuncinya atau dirumah kawan-kawanmu. tidak ada halangan bagi kamu Makan bersama-sama mereka atau sendirian. Maka apabila kamu memasuki (suatu rumah dari) rumahrumah (ini) hendaklah kamu memberi salam kepada (penghuninya yang berarti memberi salam) kepada dirimu sendiri, salam yang ditetapkan dari sisi Allah, yang diberi berkat lagi baik. Demikianlah Allah menjelaskan ayat-ayatnya (Nya) bagimu, agar kamu memabaminya. (Q.S. an-Nuur: 61)

Ayat tersebut mengandung makna kesetaraan yaitu bahwa tidak ada halangan bagi masyarakat untuk bergabung bersama dengan mereka yang berkebutuhan khusus seperti buta, pincang, bisu, tuli atau bahkan sakit. Mereka berhak untuk mendapatkan bersama, berkumpul bersama layaknya masyarakat pada umumnya, dan bahkan mereka juga berhak untuk mendapatkan pendidikan.

Pemerintah juga memberikan fasilitas dari segi pendidikan dengan membuat sekolah khusus anak penyandang disabilitas. Pada awalnya, anak difabel tidak bisa menerima kekurangan pada dirinya. Pada hakikatnya, dibutuhkan suatu proses untuk penyesuaian diri dengan kenyataan yang ada. Setelah terjadi penyesuaian, anak difabel akan berpendapat bahwa dunia ini adil dan berasumsi mereka layak berada di dunia ini serta layak mendapatkan apa yang mereka inginkan, termasuk pendidikan di sekolah.
Pendidikan sangat penting bagi semua kalangan, termasuk bagi anak difabel. Di Indonesia, pemerintah telah mendirikan beberapa Sekolah Luar Biasa (SLB) hampir diberbagai provinsi untuk menyamaratakan hak mendapatkan pendidikan. Sekolah ini didirikan oleh pemerintah untuk memfasilitasi penyandang difabel dalam mengembangkan kemampuannya dan memberi pengakuan positif terhadap keberadaannya. Namun, sedikit sekali orangtua yang menginginkan anaknya bersekolah di sana (Wasito, D. R, Sarwindah, D, \& Suliastiani, W, 2010: 138143). Pendidikan di SLB tidak sama dengan pendidikan normal karena kelainan pada setiap anak yang beragam dan tingkat usia yang berbeda. Perbedaan cara pengajaran pun sangat jauh karena anak difabel harus diajarkan secara face to face. (Winarsih, Sri Jamals, Hendra Asiah, Anisa Idris, Ferial Hadipoetro Adnan, Evita Prasojo, 2013).

Sekolah luar biasa (SLB) sendiri menyediakan guru pembimbing khusus, sarana, dan prasarana khusus bagi seluruh penyandang difabel. Mulai dari buku braile dan alat pendengar. Fasilitas seperti ruang kelas yang kondusif bagi para penyandang difabel dan kurikulum yang telah dibuat oleh pemerintah sesuai dengan kebutuhan para penyandang difabel. Namun, banyak juga penyandang difabel yang lebih memilih sekolah di sekolah umum sama seperti anak normal lainnya. Hal ini sesuai dengan Surat Keputusan Menteri Pendidikan dan 
Kebudayaan No. 2/U/1986 telah menyatakan anak cacat bisa ke sekolah umum, apabila siswa tersebut memiliki inteligensi normal.

Banyaknya anak difabel yang ingin bersekolah di sekolah umum memunculkan sebuah konsep pendidikan baru, yaitu pendidikan inklusif. Pendidikan inklusif ini dibuat agar anak difabel dapat bersekolah di sekolah umum yang terdekat serta dapat berinteraksi dengan anak-anak normal. Di setiap sekolah umum harus memiliki beberapa guru yang dapat mengajarkan pelajaran kepada anak difabel. Namun, terlalu minimnya fasilitas dan tenaga pengajar yang memiliki pengetahuan tentang disabilitas membuat anak difabel terbengkalai.

Peran sekolah sangat berpengaruh terhadap perkembangan sosial, salah satunya bagi penyandang difabel. Peranan sekolah sebenarnya untuk membentuk sikap-sikap serta kebiasaan yang wajar dan merangsang potensi yang ada dalam diri. Peranan sekolah bagi difabel untuk mengasah potensi dalam diri mereka dengan baik. Peranan guru di sekolah juga penting karena seorang guru akan memotivasi anak difabel untuk terus belajar. Selanjutnya, guru memberikan apresiasi dari segala bentuk hasil pembelajaran dari anak difabel dengan senyuman atau kata-kata yang menjadi motivasi bagi mereka.

Proses pembelajaran untuk anak berkebutuhan khusus membutuhkan kondisi khusus yang berbeda dengan pembelajaran untuk anak pada umumnya. Kurikulum dan strategi pembelajaran yang umum mungkin tidak efektif bagi mereka, karena kapasitas intelektualnya tidak memadai untuk itu. Pembelajaran harus dirubah, diatur dan atau disesuaikan dengan kondisi anak yang berkebutuhan khusus, sehingga dapat memberi hasil yang optimal. Proses ini secara umum tercakup dalam pengertian modifikasi. Modifikasi bisa dilakukan berkaitan dengan materi pelajaran, metode pembelajaran, media dan sumber pembelajaran, evaluasi dan sebagainnya. terkait dengan hal tersebut ada sejumlah konsep, strategi atau prinsip yang perlu diperhatikan dalam pembelajaran anak berkebutuhan khusus, supaya proses pembelajaran dalam implementasi pendidikan dapat optimal, yaitu Modifikasi (Modification), analisis tugas (Taskanalysis), Pembelajaran Individu (Individulized LearningProgram), dan pembelajaran tutor sebaya (PeerMediatedIntruction)

1. Modifikasi (Modification). Modifikasi adalah proses merubah strategi pembelajaran umum untuk disesuaikan dengan kondisi dan kebutuhan anak berkebutuhan khusus, sehingga pembelajaran berjalan secara efektif dan efisien. setidaknya ada tiga komponen pembelajaran utama yang dapat dimodifikasi untuk pembelajaran utama yang dapat dimodifikasi untuk pembelajaran anak berkebutuhan khusus, yaitu: a). Isi (conten). Isi berarti materi pelajaran yakni informasi, 
konsep, tema atau topik yang dipelajari oleh anak berkebutuhan khusus. Modifikasi materi menunjuk upaya merubah dan menyesuaikan materi pelajaran untuk disesuaikan dengan kondisi dan kebutuhan siswa berkebutuha khusus, b). Proses. Hal ini berkaitan dengan upaya merubah cara atau strategi mengajar sehingga lebih mudah diikuti dan dipahami oleh siswa berkebutuhan khusus. bahasa penjelasan disederhanakan, waktu belajar mungkin diperpanjang, langkah-langkah kerja disederhanakan dan dirinci secara jelas, ada pemberian contoh secara konkrit, menggunakan media yang nyata dan sederhana, proses pembelajaran mencoba melibatkan sebanyak mungkin pengalaman penginderaan secara terpadu, menghindari penjelasan teoritik dan memperbanyak latihan praktis yang konkrit, proses dikemas melalui permainan, ada demonstrasi dan lain-lain, c). Evaluasi. Penilaian tentu saja harus disesuaikan dengan tujuan dan isi pembelajaran. Ketika isi pembelajaran telah dimodifikasi maka evaluasi juga seharusnya disesuaikan. Modifikasi evaluasi bisa ditujukan kepada isi dan juga cara evaluasi. Isi evaluasi berkaitan dengan apa yang dinilai dari kemampuan siswa yang berkebutuhan khusus.
2. Fungsional. Fungsional berarti berguna, sesuatu yang dianggap berguna apabila seseorang mendapatkan atau menjalani sesuatu sesuai dengan kebutuhannya. Pembelajaran bagi anak berkebutuhan khusus sebaiknya diarahkan pada halhal yang bermamfaat bagi dirinya,

3. Analisis Tugas. Kesulitan akan semakin dirasakan ketika dihadapkan pada objek, ide, masalah atau situasi yang kompleks. Oleh karena itu, proses belajar atau tugas-tugas yang diberikan kepada mereka harus disajikan dalam pilahan-pilahan yang kecil dan sederhana, sehingga mudah untuk diikuti dan dipahami. Inilah yang dikenal dengan analisis tugas (Task Anaysis).

4. Pembelajaran Individu. Strategi ini adalah suatu pembelajaran yang menekankan perlunya siswa diberi layanan pelajaran secara individual. Dalam proses ini, pertama-tama guru harus menggambarkan kemampuan yang dimiliki. Setelah kemampuan siswa tergambar, maka selanjutnya kembangkan tujuan pembelajaran, yaitu rumusan tentang kompetensi apa yang diharapkan dicapai oleh siswa .

5. Pembelajaran Teman Sebaya (Peer Mediated Instruction). Pembelajaran teman sebaya adlaah suatu strategi atau cara mengajar dimana siswa 
dimamfaatkan media untuk terjadinya proses belajarbagi siswa lainnya. Ada beberapa bentuk pengajaran yang termasuk kedalam model pembelajaran ini diantaranya adalah siswa mengajar siswa lain (Peer Teachig Peers) dan strategi pembelajaran koperatif (Cooperative Learning) yaitu suatu strategi pembelajaran diman dibagi kedalam beberapa kelompok dan mereka bekerja sama dalam kelompok tersebut. (Ahmad, 2011).

Dengan demikian maka sudah semestinya dalam proses pembelajaran terhadap anak berkebutuhan khusus harus memperhatikan strategi yang tepat dan memberikan perhatian terhadap anak berkebutuhan khusus dan jangan menjauhi mereka, karena mereka membutuhkan sentuhan perhatian dan kasih sayang dan mereka sama dan setara dengan anak lainnya.

Istilah inklusi berasal dari bahasa ingris "inclusion" yang berarti sebagai penerimaan anak-anak yang memiliki hambatan ke dalam kurikulum, lingkungan, interaksi sosial dan konsep diri atau visi misi sekolah Inklusif juga dapat diartikan sebagai cara berfikir dan bertindak yang memungkinkan setiap individu merasakan diterima dan dihargai. Lebih jauh lagi inklusif berarti bahwa bahwa semua anak dapat diterima mskipun konsep semua anak harus cukup jelas, dan masih sulit bagi banyak orang untuk memahaminya. (Amor et al., 2019).
Pendidikan inklusif pada dasarnya adalah proses untuk membuat semua peserta didik, termasuk di dalamnya kelompok yang tereksklusi, dapat belajar dan berpartisipasi secara efektif dalam sekolah mainstream tanpa ada yang terluka dan terdiskriminasi. Pemerintah melalui kebijakannya pendidikan inklusif dipahami sistem penyelenggaraan pendidikan yang memberikan kesempatan kepada semua peserta didik yang memiliki kelainan dan memiliki potensi kecerdasan dan/atau bakat istimewa untuk mengikuti pendidikan atau pembelajaran dalam lingkungan pendidikan secara bersama-sama dengan peserta didik pada umumnya. (Kemendikbud, 2009).

Hallahan memberikan pengertian Pendidikan inklusif sebagai pendidikan yang menempatkan semua peserta didik berkebutuhan khusus dalam sekolah reguler sepanjang hari. Dalam pengertian ini Pendidikan inklusif diselenggarakan untuk mewadahi anak berkebutuhan khusus dalam mengenyam pendidikan yang terintegrasi dalam sekolah regular yang dilaksanakan secara berkelanjutan. (de Bruin, 2019).

Sementara itu Baihaqi dan Sugiarmin menyatakan bahwa hakikat inklusif adalah mengenai hak setiap siswa atas perkembangan individu, sosial, dan intelektual. Pandangan ini menegaskan bahwa pendidikan yang inklusif memandang peserta didik adalah sama-sama memiliki hak untuk mengembangkan semua potensinya tanpa ada pembedaan. 
Sekolah inklusif merupakan sekolah yang menampung semua murid dalam sekolah yang sama, dengan program pendidikan menantang, layak tetapi sesuai kebutuhan individu, tempat setiap anak diterima sebagai bagian anggota masyarakat agar anak mencapai keberhasilannya dan terpenuhi kebutuhannya(Sunardi, 2005: 23). Ini menunjukkan bahwa pendidikan inklusif sebagai suatu sistem yang memungkinkan anak berkebutuhan khusus mendapatkan layanan dalam sekolah terdekat dengan lingkungan tempat tinggalnya.

Dengan demikian pendidikan inklusif merupakan pendidikan yang diselenggarakan dan diperuntukkan tidak hanya mereka anakanak yang memiliki kebutuhan khusus atau keluarbiasaan tetapi juga diintegrasikan bersama anak-anak normal pada umumnya.

Buku pedoman umum Penyelenggaraan Pendidikan Inklusi Direktorat PSLB diuraikan bahwa tujuan penyelenggaraan pendidikan inklusi di indonesia adalah:

a. Untuk memberikan kesempatan yang seluas-luasnya kepada semua anak mendapatkan pendidikan yang layak sesuai dengan kebutuhanya, termasuk anak-anak berkebutuhan khusus.

b. Membantu mempercepat program wajib belajar pendidikan dasar

c. Membantu meningkatkan mutu pendidikan dasar dan menengah dengan menekan angka tinggal kelas dan putus sekolah. d. Menciptakan sistem pendidikan yang menghargai keanekaragaman, tidak diskriminatif, serta ramah terhadap pembelajaran.

e. Memenuhi amanah konstitusi. (Kemendikbud, 2017b).

Tujuan pendidikan inklusi di atas dapat disimpulkan bahwa tujuan pendidikan inklusi adalah untuk menjamin hak setiap warga sekolah mendapatkan pendidikan, menghilangkan diskrimitasi terhadap anak berkebutuhan khusus dan membantu meningkatkan mutu pendidikan.

Tujuan praktis yang ingin dicapai dalam pendidikan inklusif meliputi tujuan yang dapat dirasakan langsung oleh anak, guru, orang tua dan masyarakat. Secara lebih rinci, yang menjadi tujuan yang ingin dicapai oleh anak dalam mengikuti kegiatan belajar dalam setting inklusi antara lain:1).Berkembangnya kepercayaan pada diri anak, merasa bangga pada diri sendiri atas prestasi yang diperolehnya, (2) Anak dapat belajar secara mandiri dengan mencoba memahami dan menerapkan pelajaran yang diperoleh di sekolah ke dalam kehidupan sehari-hari di lingkungannya, (3) Anak mampu berinteraksi secara aktif bersama teman-temannya, bersama guru-guru yang berada di lingkungan sekolah dan masyarakat, (4) Anak dapat belajar untuk menerima adanya perbedaan, dan mampu beradaptasi dalam mengatasi perbedaan tersebut sehingga secara keseluruhan anak 
menjadi kreatif dalam pembelajaran.

(Kemendikbud, 2017a).

\section{SIMPULAN}

Anak berkebutuhan khusus di definisikan sebagai anak yang memerlukan pendidikan dan layanan khusus untuk mengembangkan potensi kemanusiaan mereka secara sempurna. Penyebutan sebagai anak berkebutuhan khusus, dikarenakan dalam memenuhi kebutuhan hidupnya, anak ini membutuhkan bantuan layanan pendidikan, layanan sosial, layanan bimbingan dan konseling, dan berbagai jenis layanan lainnya yang bersifat khusus. Dalam penanganan anak berkebutuhan khusus, terdapat tiga hal yang perlu diperhatikan, diantaranya yaitu penguatan kondisi mental orang tua yang memiliki anak berkebutuhan khusus, dukungan sosial yang kuat dari tetangga dan lingkungan sekitar anak berkebutuhan khusus tersebut, dan yang terakhir adalah peran aktif pemerintah dalam menjadikan pelayanan kesehatan dan konsultasi bagi anak berkebutuhan khusus. Setelah mengetahui dan memahami segala sesuatu hal yang berhubungan dengan anak berkebutuhan khusus, sangat diharapkan bagi masyarakat indonesia terutama bagi para pendidik dalam menyikapi dan mendidik anak yang menyandang berkebutuhan khusus dengan baik dan sesuai dengan yang diharapkan. Karena pada dasarnya anak seperti itu bukan malah dijauhi akan tetapi didekati dan diperlakukan sama dengan manusia normal lainnya akan tetapi caranya yang berbeda.

\section{DAFTAR PUSTAKA}

Ahmad, A.N. N. (2011). Pendidikan Agama Islam di Indonesia: Gagasan dan Realitas. Puslitbang dan diklat Kementerian Agama RI.

Amin, R. (2017). Titik Singgung Pendidikan Agama Islam dengan Paradigma Pendidikan Inklusi (Anak Berkebutuhan Khusus). Al-Makrifat: Jurnal Kajian Islam, 1(1), 1-22. http://ejournal.kopertais4.or.id/tapalkud a/index.php/makrifat/article/view/3032

Amor, A. M., Hagiwara, M., Shogren, K. A., Thompson, J. R., Verdugo, M. Á., Burke, K. M., \& Aguayo, V. (2019). International perspectives and trends in research on inclusive education: a systematic review. International Journal of Inclusive Education, 23(12), 1277-1295. https://doi.org/10.1080/13603116.2018. 1445304

Anwar, R. N., \& Zaenullah, Z. (2020). Perencanaan Pembelajaran Pendidikan Agama Islam pada Anak Berkebutuhan Khusus. Jurnal CARE (Children Advisory Research and Education), 8(1), 56-66. http://ejournal.unipma.ac.id/index.php/JPAUD /article/view/6723

Darma, I. P., \& Rusyidi, B. (2015). Pelaksanaan sekolah Inklusi di Indonesia. Prosiding Penelitian Dan Pengabdian Kepada Masyarakat, 2(2), 110-118. http://journal.unpad.ac.id/prosiding/arti cle/view/13530

de Bruin, K. (2019). The Impact of Inclusive Education Reforms on Students with Disability: an International Comparison. International Journal of Inclusive Education, 23(7-8), 811-826. https://doi.org/10.1080/13603116.2019. 1623327 
Dermawan, O. (2013). Strategi Pembelajaran bagi Anak Berkebutuhan Khusus di SLB. Psympathic: Jurnal Ilmiah Psikologi, 6(2), 886-897.

https://doi.org/10.15575/psy.v6i2.2206

Hanum, L. (2014). Pembelajaran Pai Bagi Anak Berkebutuhan Khusus. Jurnal Pendidikan Agama Islam, 11(2), 217-236. https://doi.org/10.14421/jpai.2014.11205

Hasbi, M., \& Restuningsih, K. (2018). Pedoman Penyelenggaraan Pendidikan Anak Usia Dini Inklusif. Direktorat Pembinaan Pendidikan Anak Usia Dini Direktorat Jenderal Pendidikan Anak Usia Dini dan Pendidikan Masyarakat Kementerian Pendidikan dan Kebudayaan.

Kemendikbud. (2009). Peraturan Menteri Pendidikan Nasional Republik Indonesia Nomor 70 tahun 2009 tentang Pendidikan Inklusif bagi Peserta Didik yang Memiliki Kelainan dan Memiliki Potensi Kecerdasan dan/atau Bakat Istimewa. Kementerian Pendidikan dan Kebudayaan.

Kemendikbud. (2017a). Peraturan Menteri Pendidikan dan Kebudayaan Republike Indonesia Nomor 30 tahun 2017 tentang Pelibatan Keluarga pada Penyelenggaraan Pendidikan. Kementerian Pendidikan dan Kebudayaan.

Kemendikbud. (2017b). Petunjuk Teknis Pelibatan Orang Keluarga pada Penyelenggaraan Sekolah Luar Biasa. Kementerian Pendidikan dan Kebudayaan.

Maftuhin, M., \& Fuad, A. J. (2018). Pembelajaran Pendidikan Agama Islam Pada Anak Berkebutuhan Khusus. Journal An-Nafs: Kajian Penelitian Psikologi, 3(1), 50-18.

https://doi.org/10.33367/psi.v3i1.502

Perdana, G. K. A., \& Dewi, K. S. (2015). Kebahagiaan pada Ibu yang Memiliki Anak Difabel. Jurnal Empati, 4(4), 66-72. https:/ / ejournal3.undip.ac.id/index.php/ empati/article/view/13554
Pratiwi, J. C. (2016). Sekolah Inklusi Untuk Anak Berkebutuhan Khusus: Tanggapan terhadap Tantangan Kedepannya. Prosiding Ilmu Pendidikan, 1(2), 50-70. https://jurnal.fkip.uns.ac.id/index.php/p ip/article/view/7725

Rachman, R. F. (2020). Kebijakan Pendidikan Anak Berkebutuhan Khusus di Surabaya dalam Perspektif Islam. Bidayatuna: Jurnal Pendidikan Guru Mandrasah Ibtidaiyah, 3(1), 125-143.

https://doi.org/10.36835/bidayatuna.v3i 01.518

Rani, K., \& Jauhari, M. N. (2018). Keterlibatan orangtua dalam penanganan anak berkebutuhan khusus. Jurnal Abadimas Adi Buana, 2(1), 55-64. https://doi.org/10.36456/abadimas.v2.i1 .a1636

Sahara, S., Hardi, V. A., \& Fauziddin, M. (2020). Upaya Meningkatkan Hafalan Bacaan dan Gerakan Shalat dengan Media Audio Visual (Video) pada Anak Usia Dini di Desa Gerbang Sari, Kecamatan Tapung Hilir Kabupaten Kampar. Journal on Teacher Education, 2(1), 137-145.

Sheehy, N., Chapman, A. J., \& Conroy, W. A. (2016). Biographical Dictionary of Psychology. Routledge.

Udhiyanasari, K. Y. (2019). Sikap Guru terhadap Anak Berkebutuhan Khusus di Sekolah Inklusi. JOEAI: Journal of Education and Instruction, 2(1), 15-24. https://doi.org/10.31539/joeai.v2i1.584

Ulwan, A. N. (2017). Pedoman Pendidikan Anak dalam Islam. As-Syifa Semarang.

Wathoni, K. (2013). Implementasi Pendidikan Inklusi dalam Pendidikan Islam. Ta'allum: Jurnal Pendidikan Islam, 1(1), 99-109. https://doi.org/10.21274/taalum.2013.1. 1.99-109

Winarsih, Sri Jamals, Hendra Asiah, Anisa Idris, Ferial Hadipoetro Adnan, Evita Prasojo, B. (2013). Panduan Penanganan 


\section{Fitrah: Journal of Islamic Education}

Anake Berkebutuban Khusus Bagi Pendamping (Orang Tua, Keluarga, dan Masyarakat). Kementerian Pemberdayaan Perempuan dan Perlindungan Anak Republik Indonesia.

Yulisetyaningrum, Y., Masithoh, A. R., \& Alfijannah, I. Z. (2018). Hubungan dukungan sosial dengan kemampuan sosialisasi anak autisme di Yayasan Pondok Pesantren ABK Al-Achsaniyyah Kudus tahun 2017. Jurnal Ilmu Keperawatan dan Kebidanan, 9(1), 44-50. http://dx.doi.org/10.26751/jikk.v9i1.399

Zein, A. (2018). Strategi Pembelajaran Pendidikan Agama Islam Pada Anak Berkebutuban Kbusus (Abk) Tunarungu di SLB Abc Taman Pendidikan Islam Medan Universitas Islam Negeri Sumatea Utara Medan]. http://repository.uinsu.ac.id/4145/

Zulaikhah, D., Sirojuddin, A., \& Aprilianto, A. (2021). Analisis Pembelajaran Pendidikan Agama Islam Kurikulum 2013 Bagi Anak Berkebutuhan Khusus. Tafkir: Interdisciplinary Journal of Islamic Education, 1(1), $54-71$. https://doi.org/10.31538/tijie.v1i1.6 